\title{
EUROPEAN SYNCHROTRON RADIATION FACILITY
}

\author{
R. HAENSEL \\ ESRF, BP220, 38043 Grenoble Cedex, France
}

European Synchrotron Radiation Facility (ESRF) is the first representant of a new (the third) generation of synchrotron radiation sources delivering high brilliance radiation in the hard X-rays. The first generation sources were initially built as part of high-energy physics programs and used as synchrotron radiation sources in a parasitic mode. Some are still used this way, some are operated for both programs in a time-sharing mode while others have been totally converted into dedicated synchrotron radiation sources. The second generation sources are those which were exclusively designed as dedicated synchrotron radiation sources. They have emittances in the range of $100 \mathrm{~nm}$ rad. The main radiation sources are bending magnets, a few insertion devices may have been added. The third generation sources finally have a lower emittance $(<20 \mathrm{~nm}$ rad) and many long straight sections for a maximum of insertion devices.

In the following we give a short review of the history of the ESRF:

13 September 1976 1st meeting of a working group on "Synchrotron Radiation" created by the European Science Foundation (ESF)

Chairman: H. Maier-Leibnitz

December 1977 Black Book

May 1979

Blue Book (Ed. Y. Farge)

December 1982 Yellow Book (Ed. J. Als-Nielsen)

October 1984 Green Book (Eds. B. Buras, S. Tazzari)

$* * * * * * * * * * * * * * * * * * * * * * * * * * * * * * * * * * * * * * * * * * * * * * * * * * * * * * * * * *$

April 1985

June 1985

December 1985
Decision on the site: Grenoble

1st meeting of the provisional ESRF Council

Memorandum of Understanding concerning the Preparatory

Phase of the ESRF: France, Germany, Italy, U.K., Spain 
April 1986

January-June 1987

February 1987

July-December 1987

December 1987

January 1988

16 December 1988

April 1990

November 1990

12 November 1990

21 December 1990

January 1991

16 May 1991

2 September 1991

12 November 1991

9 December 1991
Start of work of the ESRF team

1st prolongation of the Preparatory Phase

Red Book (Foundation Phase Report) submitted to the Council

2nd prolongation of the Preparatory Phase

Protocol: France, Germany, Italy, U.K., Spain,

Switzerland, and 4 Nordic countries (Denmark,

Finland, Norway, Sweden)

Start of construction

Signing of Convention, Statutes and Final Act by France, Germany, Italy, U.K., Spain, Switzerland, Belgium and 4 Nordic countries (Denmark, Finland, Norway, Sweden)

Execution of building construction contract A:

Excavation, drainage and sewers

Signing of building construction contract $B$ :

Machine utility buildings, storage ring tunnel, experimental hall, technical utility buildings

Start of building construction;

$60 \%$ of equipment for the accelerator ordered Start of installation of the Booster Synchrotron Foundation of a consortium BENESYNC aiming at the accession of the Netherlands to ESRF in the framework of a consortium with Belgium which was already contracting party of ESRF Signing of building construction contract $\mathrm{C}$ : central building (for laboratories and offices), joint ESRF/ILL building, landscaping

Delivery of preinjector (linear accelerator);

Experimental confirmation (by an ESRF team in collaboration with NSLS, Brookhaven)

of the potential of cryo-cooled silicon single crystals to preserve the high brilliance of ESRF's X-ray beams

First electron beam in the preinjector

First electron beam $(200 \mathrm{MeV})$ in the Booster Synchrotron

Acceleration to $6 \mathrm{GeV}$

Accession of the Netherlands to the ESRF Convention The list of the Contracting Parties of the ESRF and their financial contributions to the construction/ /operation costs (in\%) now reads as follows: 
France (33/27.5)

Germany (23/25.5)

Italy $(14 / 15)$

United Kingdom (12/14)

BENESYNC (Belgium, The Netherlands) (4/4)

NORDSYNC (Denmark, Finland, Norway, Sweden) (4/4)

Spain (4/4)

Switzerland (4/4)

28 February 1992 First electrons circulating in the storage ring

June 1992

$6 \mathrm{GeV}$ (target value achieved);

$100 \mathrm{~mA}$ in multi-bunch mode (target value achieved);

$3 \mathrm{~mA}$ in single-bunch mode (target value: $7.5 \mathrm{~mA}$ );

2 hours lifetime at $100 \mathrm{~mA}$ (target value: 10 hours);

$8 \mathrm{~nm}$ rad emittance at low intensity (target value: $7 \mathrm{~nm}$ rad for all intensities)

3 July, 1992 First X-rays from an undulator in the experimentall hall

The commissioning period of the source will finish before the end of 1992, i.e. 6 months earlier than initially foreseen in the Foundation Phase Report (1987).

The beamline program foresees $30 \mathrm{ESRF}$-Funded Beamlines. The main characteristics of the first 20 beamlines are given in the following Table. For a first set of (at least) 7 beamlines the commissioning period will start in 1993, users operation is foreseen to start in 1994.

TABLE

ESRF-Funded Beamlines.

\begin{tabular}{|c|c|c|c|}
\hline & Beamline & Scientific goals & Source \\
\hline 1. & Microfocus & $\begin{array}{l}\text { Microdiffraction; } \\
\text { Small-angle scattering; High pressure }\end{array}$ & Undulator $0.8-3.0 \AA$ \\
\hline 2. & $\begin{array}{l}\text { Multipole wiggler/ } \\
\text { Materials science }\end{array}$ & $\begin{array}{l}\text { Small molecule crystallography; } \\
\text { Magnetic scattering }\end{array}$ & Wiggler $4-60 \mathrm{keV}$ \\
\hline 3. & $\begin{array}{l}\text { Multipole wiggler } \\
\text { White beam }\end{array}$ & $\begin{array}{l}\text { Laue protein crystallography; } \\
\text { High pressure ED; } \\
\text { Monochromatic option }\end{array}$ & Wiggler $4-60 \mathrm{keV}$ \\
\hline 4. & High brilliance & $\begin{array}{l}\text { Real time small-angle scattering; } \\
\text { Monochromatic macromolecular } \\
\text { crystallography }\end{array}$ & $\begin{array}{l}\text { Undulator } \lambda \text { tunable } \\
\text { around } 1 \AA\end{array}$ \\
\hline 5. & $\begin{array}{l}\text { High energy } \\
\text { X-ray scattering }\end{array}$ & $\begin{array}{l}\text { Gamma-ray diffraction; } \\
\text { Small-angle scattering; } \\
\text { Compton scattering }\end{array}$ & Wa velength shifter \\
\hline 6. & $\begin{array}{l}\text { Circular } \\
\text { polarization }\end{array}$ & $\begin{array}{l}\text { Dichroism in EXAFS, SEXAFS; } \\
\text { Spin-dependent photoemission; } \\
\text { Microscopy at } 2.5 \mathrm{keV}\end{array}$ & $\begin{array}{l}\text { Helical undulator } \\
E \leq 4 \mathrm{keV}\end{array}$ \\
\hline
\end{tabular}




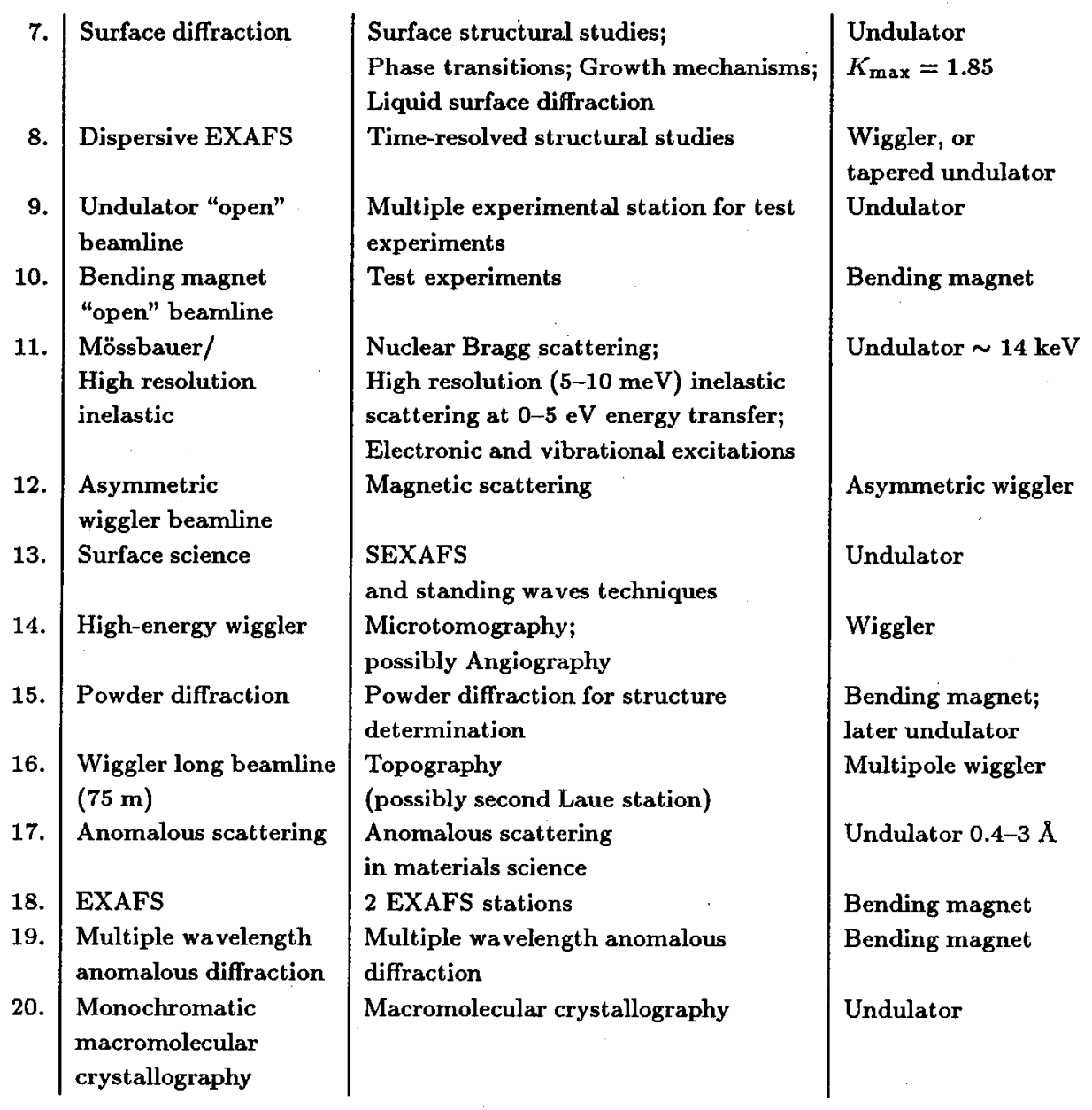

Besides the 30 ESRF-Funded beamlines, mostly on insertion devices, there will be a number of beamlines on bending magnets, which are financed and operated by Collaborating Research Groups (CRG) from the member countries under special arrangement with ESRF. 